\title{
2-Hydroxy-1-((2-(pyridin-2-yl)hydrazono)methyl)tryptanthrin as a Fluorescent Chemosensor for Metal Ions
}

\author{
Jun Kawakami*, Masayoshi Sasagawa and Shunji Ito \\ Graduate School of Science and Technology, Hirosaki University, 3 Bunkyo-cho, Hirosaki, Aomori 036-8561, Japan \\ * Corresponding author: Fax: 81-172-39-3541, e-mail: jun@hirosaki-u.ac.jp
}

\begin{abstract}
2-Hydroxy-1-((2-(pyridin-2-yl)hydrazono)methyl)tryptanthrin $\quad$ (T2OH1CH=N-NH-Pyri) was synthesized and applied as a fluorescent chemosensor for metal ions. We investigated the metalion recognition of T2OH1CH=N-NH-Pyri in separate $\mathrm{Li}^{+}, \mathrm{Na}^{+}, \mathrm{K}^{+}, \mathrm{Mg}^{2+}, \mathrm{Ca}^{2+}, \mathrm{Ba}^{2+}, \mathrm{Fe}^{2+}, \mathrm{Fe}^{3+}$, $\mathrm{Co}^{2+}, \mathrm{Ni}^{2+}, \mathrm{Cu}^{2+}, \mathrm{Ag}^{+}, \mathrm{Zn}^{2+}, \mathrm{Cd}^{2+}, \mathrm{Al}^{3+}$, and $\mathrm{Pb}^{2+}$ acetonitrile solutions. $\mathrm{Li}^{+}, \mathrm{Na}^{+}, \mathrm{K}^{+}, \mathrm{Ca}^{2+}, \mathrm{Ba}^{2+}$, and $\mathrm{Ag}^{+}$had no effect on the shape and intensity of the fluorescence spectrum of the chemosensor. T2OH1CH=N-NH-Pyri formed a 1:1 complex with $\mathrm{Mg}^{2+}, \mathrm{Fe}^{2+}, \mathrm{Fe}^{3+}, \mathrm{Co}^{2+}, \mathrm{Ni}^{2+}, \mathrm{Cu}^{2+}, \mathrm{Zn}^{2+}, \mathrm{Cd}^{2+}$, $\mathrm{Al}^{3+}$, and $\mathrm{Pb}^{2+}$. The fluorescence intensity of the sensor increased for $\mathrm{Mg}^{2+}, \mathrm{Zn}^{2+}, \mathrm{Cd}^{2+}, \mathrm{Al}^{3+}$, and $\mathrm{Pb}^{2+}$, and decreased for $\mathrm{Fe}^{2+}, \mathrm{Fe}^{3+}, \mathrm{Co}^{2+}, \mathrm{Ni}^{2+}$, and $\mathrm{Cu}^{2+}$.
\end{abstract}

Key words: tryptanthrin, fluorescent chemosensor, metal ion

\section{INTRODUCTION}

The synthesis and application of fluorescent tryptanthrin derivatives are generating widespread research interest [15]. These compounds absorb and emit radiation at long wavelengths and are used in a diverse range of fields and for a variety of functions, including as labeling reagents, chemosensors, laser dyes, photosensitizers, and in the manufacture of fluorescent organic devices. However, our research is concerned with the use of organic fluorescent dyes as imaging probes in biological research. The nearinfrared (NIR) region $(650-900 \mathrm{~nm})$ is referred to as the "optical window" for cells and tissues because of the lack of efficient endogenous absorbers in this spectral range. Consequently, NIR radiation has a high penetration depth (of the order of a few millimeters) for most biological tissues [6]. Organic fluorescent dyes that emit NIR fluorescence are preferable for applications in biological systems because their use ameliorates problems associated with auto-fluorescence and photodamage to living cells.

2-Hydroxytryptanthrin (T2OH, Fig. 1a) has been applied as a NIR dye for fluorescent imaging. The absorption maxima $\left(\lambda_{\mathrm{a}, \max }\right)$ of $\mathbf{T 2 O H}$ in the $\mathrm{pH}$ ranges $1.3-7.2$ and 8.5-10.6 are $c a .410$ and $495 \mathrm{~nm}$, respectively, and its fluorescence maximum $\left(\lambda_{\mathrm{f}, \max }\right)$ is $c a .660 \mathrm{~nm}$, regardless of $\mathrm{pH}$. The sodium salt of T2OH (sodium tryptanthrin-2-olate, T2ONa, Fig. 1b) is water soluble and its $\lambda_{\mathrm{f}, \max }$ is $c a .660$ $\mathrm{nm}$ in both aprotic and protic solvents [5].

The metal-ion recognition capabilities of $\mathbf{T 2 O H}$ and its derivative 1-formyl-2-hydroxytryptanthrin (T2OH1CHO, Fig. 1c) have been investigated [7]. T2OH was demonstrated to be a fluorescent chemosensor for $\mathrm{Cu}^{2+}$ and $\mathrm{Al}^{3+}$ in acetonitrile solutions, and was also applied as an NIR fluorescent $\left(\mathrm{l}_{\mathrm{f}, \max }>650 \mathrm{~nm}\right)$ labeling reagent. However, it was unable to detect changes in an aqueous $(\mathrm{DMSO} / \mathrm{H} 2 \mathrm{O}=1 / 9, \mathrm{v} / \mathrm{v})$ environment. Conversely, the fluorescences of an acetonitrile solution of T2OH1CHO at ca. 590 and 520 were shown to decrease and increase, respectively, upon addition of $\mathrm{Al}^{3+}$. Furthermore, T2OH1CHO selectively detects $\mathrm{Al}^{3+}$ in aqueous solutions. Thus, T2OH1CHO is a good fluorescent chemosensor for
$\mathrm{Al}^{3+}$ in both acetonitrile and aqueous solutions.

In the current study, the novel 2-hydroxytryptanthrin derivative 2-hydroxy-1-((2-(pyridin-2-yl)hydrazono) methyl)tryptanthrin (T2OH1CH=N-NH-Pyri, Fig. 1d) was synthesized and its metal-ion recognition properties were investigated using acetonitrile solutions of $\mathrm{Li}^{+}, \mathrm{Na}^{+}$, $\mathrm{K}^{+}, \mathrm{Mg}^{2+}, \mathrm{Ca}^{2+}, \mathrm{Ba}^{2+}, \mathrm{Fe}^{2+}, \mathrm{Fe}^{3+}, \mathrm{Co}^{2+}, \mathrm{Ni}^{2+}, \mathrm{Cu}^{2+}, \mathrm{Ag}^{+}, \mathrm{Zn}^{2+}$, $\mathrm{Cd}^{2+}, \mathrm{Al}^{3+}$, and $\mathrm{Pb}^{2+}$. a)<smiles>O=C1CCCC12CC1CCC(O)CC1C2=O</smiles>

T2OH

c)<smiles>O=CC1C(O)CCC2CC3(CCCC3=O)C3(CCCC3)C21</smiles>

T2OH1CHO b)

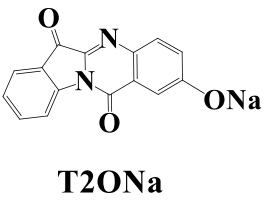

d)<smiles>CCC1C(O)CCC2NC(=O)C3CCCC3C21</smiles>

T2OH1CH=N-NH-Pyri

Fig.1 Structures of (a) T2OH; (b) T2ONa; (c) T2OH1CHO; and (d) T2OH1CH=N-NH-Pyri.

\section{EXPERIMENTAL \\ 2.1 Synthesis}

T2OH1CH=N-NH-Pyri was synthesized according to Scheme 1. The synthesis of 1-formyl-2-hydroxytyuptanthrin (T2OH1CHO) was performed using the Duff reaction [8]. The synthesis of T2OH1CH=N-NH-Pyri was performed according to a previously reported method [9] with some slight modifications.

Hexamethylenetetramine (HMTA) $(501 \mathrm{mg}, 3.57 \mathrm{mmol})$ was added to a solution of T2OH [5] (633 $\mathrm{mg}, 2.40 \mathrm{mmol}$ ) in $20 \mathrm{~mL}$ of trifluoroacetic acid (TFA). The solution was refluxed for $24 \mathrm{~h}$ protected from light. After cooling the 


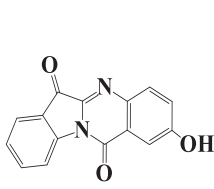

T2OH

stirred for $24 \mathrm{~h}$ at $\mathrm{rt}$

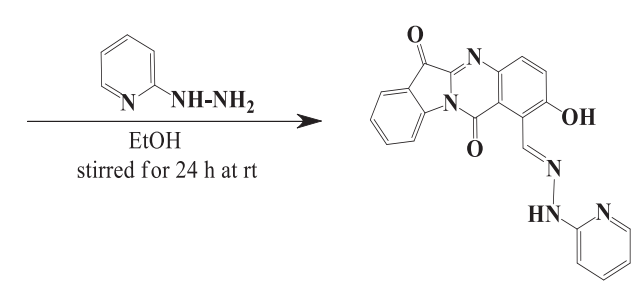

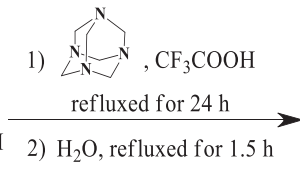

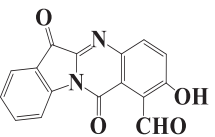

T2OH1CHO
T2OH1CH=N-NH-Pyri

Scheme 1 Synthesis of T2OH1CH=N-NH-Pyri.

solution to room temperature, $20 \mathrm{~mL}$ of water was added, and the solution was refluxed for a further $90 \mathrm{~min}$. The solution was then cooled to room temperature followed by cooling in a refrigerator. The reaction mixture was suction filtered, and the solid yellow residue was thoroughly washed with water. Pure T2OH1CHO (584 mg) was obtained in $83 \%$ yield. Next, T2OH1CHO (58.5 mg, 0.201 mmol) was dissolved in $10 \mathrm{~mL}$ ethanol and 2 hydrazinylpyridine $(21.6 \mathrm{mg}, 0.198 \mathrm{mmol})$ was added to the solution. The mixture was stirred at room temperature for $24 \mathrm{~h}$. The solvent was then removed by evaporation, and the red residue was washed with hexane and ethanol to yield T2OH1CH=N-NH-Pyri $(62.0 \mathrm{mg})$ in $81 \%$ yield. The electron-spray ionization (ESI) mass spectra of T2OH1CHO and T2OH1CH=N-NH-Pyri showed their corresponding molecular ion peaks, and the ${ }^{1} \mathrm{H}$ NMR spectra confirmed that the compounds were appropriately synthesized.

T2OH1CHO: ${ }^{1} \mathrm{H}$ NMR $\left(500 \mathrm{MHz}, \mathrm{DMSO}-d_{6}\right) \delta 7.51$ $(1 \mathrm{H}, \mathrm{td}, J=7.5 \mathrm{~Hz}, 0.8 \mathrm{~Hz}), 7.56(1 \mathrm{H}, \mathrm{d}, J=8.9 \mathrm{~Hz})$, $7.88(2 \mathrm{H}, \mathrm{m}), 8.05(1 \mathrm{H}, \mathrm{d}, J=8.9 \mathrm{~Hz}), 8.47(1 \mathrm{H}, \mathrm{d}$, $J=8.0 \mathrm{~Hz}), 11.03(1 \mathrm{H}, \mathrm{s}) 11.91(1 \mathrm{H}, \mathrm{s}) ;$ ESI-MS m/z $(\mathrm{M}+\mathrm{H})$ calcd 293.0562, found 263.0576.

T2OH1CH=N-NH-Pyri: ${ }^{1} \mathrm{H}$ NMR $(500 \mathrm{MHz}$, DMSOd6) $\delta 6.88(1 \mathrm{H}, \mathrm{s}), 7.40-7.80(9 \mathrm{H}, \mathrm{m}), 8.52(1 \mathrm{H}, \mathrm{d}, J$ $=7.5 \mathrm{~Hz}), 10.11(1 \mathrm{H}, \mathrm{s}), 11.65(1 \mathrm{H}, \mathrm{s})$; ESI-MS m/z $(\mathrm{M}+\mathrm{H})$ calcd 384.1097, found 384.0903 .

\subsection{Measurements}

Stock solutions of $\mathbf{T 2 O H} \mathbf{1 C H}=\mathbf{N}-\mathbf{N H}-\mathbf{P y r i}$ were prepared by dissolving a weighed amount of the compound in acetonitrile. The metal ions ([Metal ions] $=1-100 \mu \mathrm{M}$ ) were titrated against $\mathbf{T 2 O H} \mathbf{C} \mathbf{C H}=\mathbf{N}-\mathbf{N H}-\mathbf{P y r i}$ solutions $([\mathbf{T} 2 \mathrm{OH} 1 \mathrm{CH}=\mathbf{N}-\mathbf{N H}-\mathbf{P y r i}]=10 \mu \mathrm{M})$ in a spectrophotometric cell with a path length of $1 \mathrm{~cm}$. UV-Vis spectra $(250-800 \mathrm{~nm})$ of the solutions were recorded at room temperature using a JASCO V-670 spectrophotometer after the separate addition of each of the 16 metal salts $\mathrm{LiClO}_{4}$, $\mathrm{NaClO}_{4}, \quad \mathrm{KClO}_{4}, \quad \mathrm{Mg}\left(\mathrm{ClO}_{4}\right)_{2}, \quad \mathrm{Ca}\left(\mathrm{ClO}_{4}\right)_{2}, \quad \mathrm{Ba}\left(\mathrm{ClO}_{4}\right)_{2}$, $\mathrm{Fe}\left(\mathrm{ClO}_{4}\right)_{2}, \mathrm{Fe}\left(\mathrm{ClO}_{4}\right)_{3}, \mathrm{Co}\left(\mathrm{ClO}_{4}\right)_{2}, \mathrm{Ni}\left(\mathrm{ClO}_{4}\right)_{2}, \mathrm{Cu}\left(\mathrm{ClO}_{4}\right)_{2}$, $\mathrm{AgClO}_{4}, \mathrm{Zn}\left(\mathrm{ClO}_{4}\right)_{2}, \mathrm{Cd}\left(\mathrm{ClO}_{4}\right)_{2}, \mathrm{Al}\left(\mathrm{ClO}_{4}\right)_{3}$, and $\mathrm{Pb}\left(\mathrm{ClO}_{4}\right)_{2}$. The same titrations were also performed using fluorescence spectra measurements. The fluorescence spectra were measured between 400 and $900 \mathrm{~nm}$ with a Hitachi F-4500 fluorometer. ${ }^{1} \mathrm{H}$ NMR spectra were recorded on a JEOL
JNM-ECA 500 spectrometer in deuterated dimethyl sulfoxide (DMSO- $d_{6}$ ) with tetramethylsilane as an internal standard. High-resolution mass spectra were obtained using ESI on a HITACHI NanoFrontier LD spectrometer.

\section{RESULTS AND DISCUSSION}

The UV-Vis absorption and fluorescence of an acetonitrile solution of $\mathbf{T 2 O H} \mathbf{C H}=\mathbf{N}-\mathbf{N H}-\mathrm{Pyri}$ were measured at room temperature. To this solution, 16 different metal salts were separately added at concentrations up to 10-times that of the sample $(10 \mu \mathrm{M})$. When $\mathrm{Li}^{+}, \mathrm{Na}^{+}, \mathrm{K}^{+}, \mathrm{Ca}^{2+}, \mathrm{Ba}^{2+}$, and $\mathrm{Ag}^{+}$were added to the solution, the shape and intensity of the fluorescence spectra did not change. Figure 2 shows the absorption and fluorescence spectra of T2OH1CH=N-NH-Pyri with and without $\mathrm{K}^{+}$as a typical example. The collision quenching between $\mathbf{T 2 O H} \mathbf{C H}=\mathbf{N}-\mathbf{N H}-\mathbf{P y r i}$ and the metal ions resulted in slight changes in the fluorescence spectra.

(a)

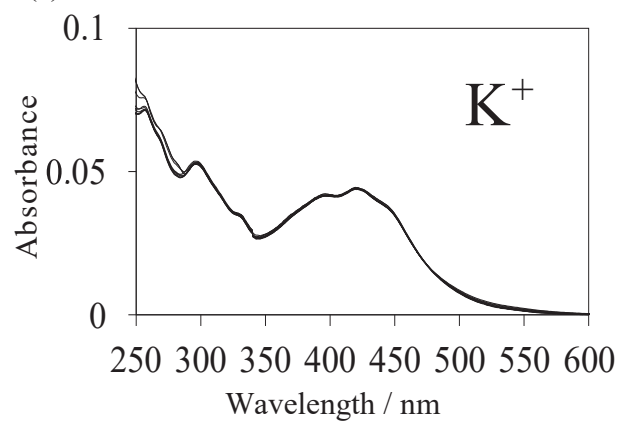

(b)

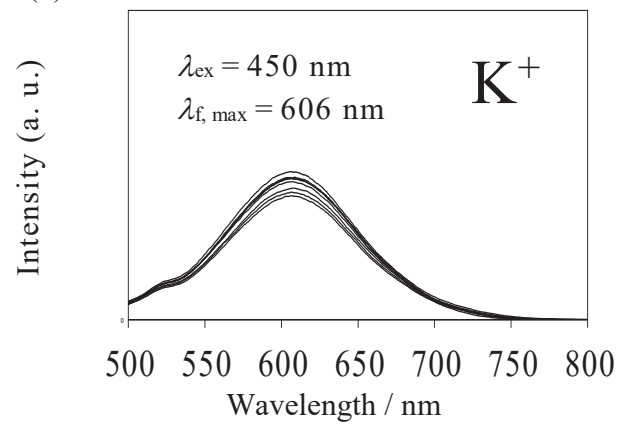

Fig.2 Spectral changes in the (a) UV-Vis and (b) fluorescence spectra of T2OH1CH=N-NH-Pyri $(10 \mu \mathrm{M})$ with $\mathrm{K}^{+}$in an acetonitrile solution; $\left[\mathrm{K}^{+}\right] /[\mathbf{T} 2 \mathrm{OH} 1 \mathbf{C H}=\mathbf{N}-$ NH-Pyri] $=0-10$.

From the absorbance titration curves, it was found that T2OH1CH=N-NH-Pyri forms a 1:1 complex with $\mathrm{Mg}^{2+}$, $\mathrm{Fe}^{2+}, \mathrm{Fe}^{3+}, \mathrm{Co}^{2+}, \mathrm{Ni}^{2+}, \mathrm{Cu}^{2+}, \mathrm{Zn}^{2+}, \mathrm{Cd}^{2+}, \mathrm{Al}^{3+}$, and $\mathrm{Pb}^{2+}$. Figure 3 shows the titration curve for T2OH1CH=N-NHPyri with $\mathrm{Mg}^{2+}$ as a typical example. The titration curve monitored by absorbance at $510 \mathrm{~nm}$ shows a sharp endpoint at a ligand/ion ratio of $1: 1$ for $\mathrm{Mg}^{2+}$.

In polar solvents, $\mathbf{T 2 O H 1 C H = N - N H - P y r i ~ c h e l a t e s ~}$ metal ions via the olate anion of the hydroxy group and the nitrogen atoms (inset of Fig. 3). The fluorescence intensity increased for $\mathrm{Mg}^{2+}, \mathrm{Zn}^{2+}, \mathrm{Cd}^{2+}, \mathrm{Al}^{3+}$, and $\mathrm{Pb}^{2+}$, and decreased for $\mathrm{Fe}^{2+}, \mathrm{Fe}^{3+}, \mathrm{Co}^{2+}, \mathrm{Ni}^{2+}$, and $\mathrm{Cu}^{2+}$. Figures 4 and 5 shows the absorption and fluorescence spectra of T2OH1CH=N-NH-Pyri with and without $\mathrm{Mg}^{2+}$ and $\mathrm{Ni}^{2+}$ 


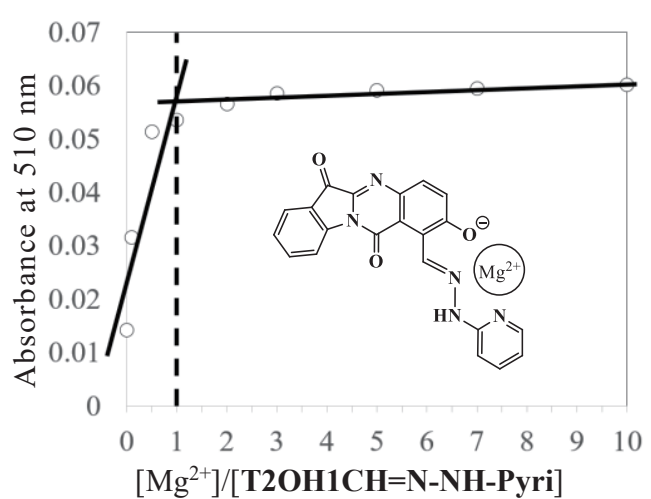

Fig.3 Absorbance at $510 \mathrm{~nm}$ for $\mathbf{T 2 O H} \mathbf{1 C H}=\mathbf{N}-\mathbf{N H}-\mathbf{P y r i}$ titrated with $\mathrm{Mg}^{2+}$ in an acetonitrile solution.
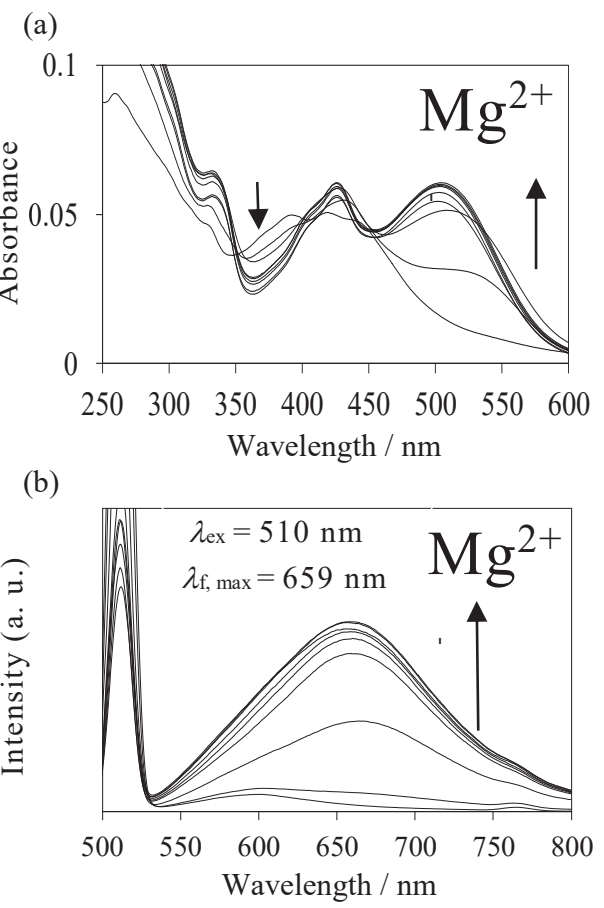

Fig.4 Spectral changes in the (a) UV-Vis and (b) fluorescence spectra of T2OH1CH=N-NH-Pyri $(10 \mu \mathrm{M})$ with $\mathrm{Mg}^{2+}$ in an acetonitrile solution. $\left[\mathrm{Mg}^{2+}\right] /[\mathbf{T} \mathbf{2 O H} \mathbf{C H}=$ N-NH-Pyri $]=0-10$.

as typical examples.

The $\lambda_{\text {f, max }}$ values for $\mathrm{Mg}^{2+}, \mathrm{Zn}^{2+}, \mathrm{Cd}^{2+}, \mathrm{Al}^{3+}$, and $\mathrm{Pb}^{2+}$, i.e., where fluorescence increases were observed, were 659 , $645,627,594$, and $630 \mathrm{~nm}$, respectively. Thus, for $\mathrm{Mg}^{2+}$, $\lambda_{\mathrm{f}, \max }$ was observed in the NIR region $(650-900 \mathrm{~nm})$. Fluorescence increases would be due to suppression of molecular motion by formation of metal complexes. That is, thermal deactivation due to internal conversion was reduced. When $\mathrm{Fe}^{2+}, \mathrm{Fe}^{3+}, \mathrm{Co}^{2+}, \mathrm{Ni}^{2+}$, and $\mathrm{Cu}^{2+}$ were individually added to the solution, the fluorescence at 606 $\mathrm{nm}$ was quenched. Transition metal ions such as $\mathrm{Cu}^{2+}$ usually behave as fluorescence quenchers via electron transfer from the excited-state fluorophore to the empty $d$ orbital [10]. Therefore, several fluorescent dyes show fluorescence-quenched responses upon the addition of transition metal salts.
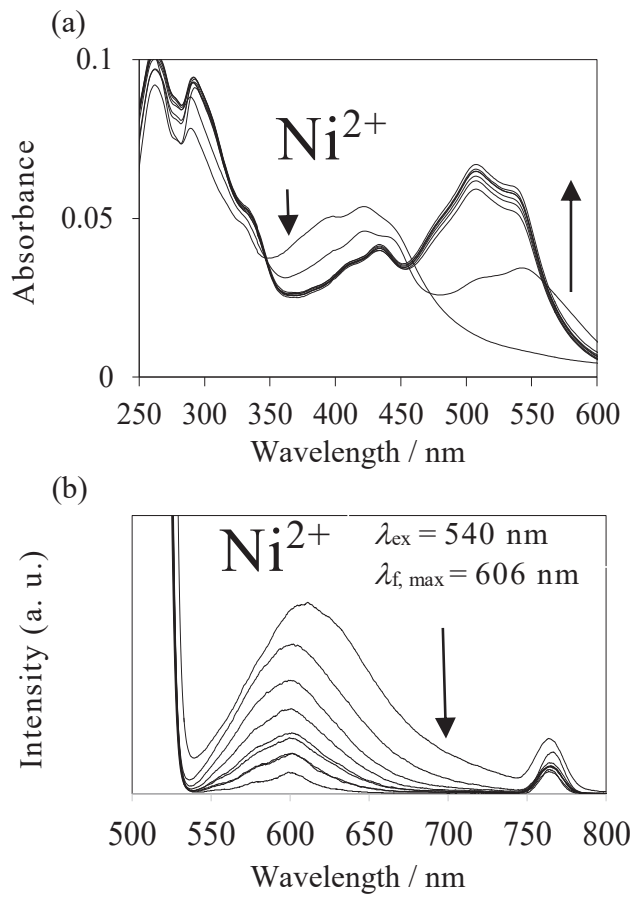

Fig.5 Spectral changes in the (a) UV-Vis and (b) fluorescence spectra of $\mathbf{T 2 O H} 1 \mathbf{C H}=\mathbf{N}-\mathbf{N H}-\mathbf{P y r i}(10 \mu \mathrm{M})$ with $\mathrm{Ni}^{2+}$ in an acetonitrile solution. $\left[\mathrm{Ni}^{2+}\right] /[\mathbf{T 2 O H} 1 \mathrm{CH}=$ N-NH-Pyri] $=0-10$.

We calculated the association constants $(K)$ for $\mathrm{Mg}^{2+}$, $\mathrm{Fe}^{2+}, \mathrm{Fe}^{3+}, \mathrm{Co}^{2+}, \mathrm{Ni}^{2+}, \mathrm{Cu}^{2+}, \mathrm{Zn}^{2+}, \mathrm{Cd}^{2+}, \mathrm{Al}^{3+}$, and $\mathrm{Pb}^{2+}$.

Even though the solvent participates in the association interaction, the solvent concentration is virtually unaffected. Therefore, we can express the interaction of the metal salts in terms of the equilibrium [11]:

$$
\mathrm{L}+\mathrm{M} \rightleftarrows \mathrm{LM}
$$

where $\mathrm{L}$ is $\mathbf{T} \mathbf{2 O H} \mathbf{C H}=\mathbf{C}-\mathbf{N H}-\mathbf{P y r i}$ and $\mathrm{M}$ is $\mathrm{Mg}^{2+}, \mathrm{Fe}^{2+}, \mathrm{Fe}^{3+}, \mathrm{Co}^{2+}, \mathrm{Ni}^{2+}, \mathrm{Cu}^{2+}, \mathrm{Zn}^{2+}$, $\mathrm{Cd}^{2+}, \mathrm{Al}^{3+}$, or $\mathrm{Pb}^{2+}$.

Furthermore, the association constants $(K)$ can be expressed as follows:

$$
\begin{aligned}
& \begin{aligned}
K= & {[\mathrm{LM}] /[\mathrm{L}][\mathrm{M}] } \\
& =[\mathrm{LM}] /\left\{\left([\mathrm{L}]_{0}-[\mathrm{LM}]\right)\left([\mathrm{M}]_{0}-[\mathrm{LM}]\right)\right\} \\
& =[\mathrm{LM}] /\left\{\left([\mathrm{L}]_{0}-[\mathrm{LM}]\right)\left([\mathrm{M}]_{0}\right)\right\}
\end{aligned} \\
& {[\mathrm{LM}]=\left\{\left(\mathrm{I}_{\mathrm{a}}-\mathrm{I}_{\mathrm{a}, 0}\right) /\left(\mathrm{I}_{\mathrm{a}, \max }-\mathrm{I}_{\mathrm{a}, 0}\right)\right\}[\mathrm{L}]_{0}}
\end{aligned}
$$

and from Eqs. 2 and 3, the following equation can be derived:

$$
1 /\left(\left(\mathrm{I}_{\mathrm{a}}-\mathrm{I}_{\mathrm{a}, 0}\right)=1 /\left\{\left(\mathrm{I}_{\mathrm{a}, \max }-\mathrm{I}_{\mathrm{a}, 0}\right) K[\mathrm{M}]_{0}\right\}+1 / \mathrm{I}_{\mathrm{a}, \max }-\mathrm{I}_{\mathrm{a}, 0}\right.
$$

where $[\mathrm{L}]_{0}$ and $[\mathrm{M}]_{0}$ are the initial concentrations of T2OH1CH=N-NH-Pyri and the metal ion, respectively, $\mathrm{I}_{\mathrm{a}}$ and $\mathrm{I}_{\mathrm{a}, 0}$ are the observed absorbances of $\mathbf{T 2 O H} 1 \mathbf{C H}=\mathbf{N}$ NH-Pyri with and without the metal ion, respectively, and $\mathrm{I}_{\mathrm{a} \text {, } \max }$ is the observed absorbance of the complex of T2OH1CH=N-NH-Pyri and the metal ion. The association 
constants were determined from the absorbance changes using Eq. 4. The values of $\log K$ for $\mathbf{T 2 O H 1 C H}=\mathbf{N}-\mathbf{N H}-$ Pyri with the metal ions are reported in Table I.

Table I Association constants $(K)$ of T2OH1CH=N-NHPyri with metal ions in acetonitrile solutions.

\begin{tabular}{lllllllllll}
\hline \multicolumn{1}{c}{$\log K$} \\
\hline $\mathrm{Mg}^{2+}$ & $\mathrm{Fe}^{2+}$ & $\mathrm{Fe}^{3+}$ & $\mathrm{Co}^{2+}$ & $\mathrm{Ni}^{2+}$ & $\mathrm{Cu}^{2+}$ & $\mathrm{Zn}^{2+}$ & $\mathrm{Cd}^{2+}$ & $\mathrm{Al}^{3+}$ & $\mathrm{Pb}^{2+}$ \\
\hline 5.8 & 6.1 & 6.3 & 6.5 & 6.0 & 6.3 & 5.7 & 5.4 & 4.5 & 4.8 \\
\hline
\end{tabular}

Thus, the stability constant of the transition metal ions $\left(\mathrm{Fe}^{2+}\right.$, $\mathrm{Fe}^{3+}, \mathrm{Co}^{2+}, \mathrm{Ni}^{2+}$, and $\mathrm{Cu}^{2+}$ ) are larger than those of the other metal ions $\left(\mathrm{Mg}^{2+}, \mathrm{Zn}^{2+}, \mathrm{Cd}^{2+}, \mathrm{Al}^{3+}\right.$, and $\left.\mathrm{Pb}^{2+}\right)$.

\section{CONCLUSIONS}

We investigated the metal-ion recognition properties of $\mathbf{T} \mathbf{2 O H} \mathbf{1 C H}=\mathbf{N}-\mathbf{N H}-\mathbf{P y r i}$ by adding $\mathrm{Li}^{+}$, $\mathrm{Na}^{+}, \mathrm{K}^{+}, \mathrm{Mg}^{2+}, \mathrm{Ca}^{2+}, \mathrm{Ba}^{2+}, \mathrm{Fe}^{2+}, \mathrm{Fe}^{3+}, \mathrm{Co}^{2+}, \mathrm{Ni}^{2+}, \mathrm{Cu}^{2+}$, $\mathrm{Ag}^{+}, \mathrm{Zn}^{2+}, \mathrm{Cd}^{2+}, \mathrm{Al}^{3+}$, and $\mathrm{Pb}^{2+}$ to acetonitrile solutions of the chemosensor. When $\mathrm{Li}^{+}, \mathrm{Na}^{+}, \mathrm{K}^{+}$, $\mathrm{Ca}^{2+}, \mathrm{Ba}^{2+}$, or $\mathrm{Ag}^{+}$were added to the solution, the shape and intensity of the fluorescence spectra did not change. $\mathbf{T 2 O H} 1 \mathrm{CH}=\mathbf{N}-\mathbf{N H}-\mathbf{P y r i}$ forms a $1: 1$ complex with $\mathrm{Mg}^{2+}, \mathrm{Fe}^{2+}, \mathrm{Fe}^{3+}, \mathrm{Co}^{2+}, \mathrm{Ni}^{2+}, \mathrm{Cu}^{2+}, \mathrm{Zn}^{2+}$, $\mathrm{Cd}^{2+}, \mathrm{Al}^{3+}$, and $\mathrm{Pb}^{2+}$. The fluorescence intensity increases for $\mathrm{Mg}^{2+}, \mathrm{Zn}^{2+}, \mathrm{Cd}^{2+}, \mathrm{Al}^{3+}$, and $\mathrm{Pb}^{2+}$, and decreases for $\mathrm{Fe}^{2+}, \mathrm{Fe}^{3+}, \mathrm{Co}^{2+}, \mathrm{Ni}^{2+}$, and $\mathrm{Cu}^{2+}$. Furthermore, for $\mathrm{Mg}^{2+}, \lambda_{\mathrm{f}, \max }$ is observed in the NIR region (650-900 nm).

$\mathrm{Mg}^{2+}$ is the fourth most abundant metal in our body and plays crucial roles in several physiological functions, such as maintaining membrane integrity, aiding nervous tissue conduction, improving neuromuscular excitability, muscle contraction, increasing hormone secretion, and assisting in intermediary metabolism [12]. Therefore, development of a fluorescent chemosensor for $\mathrm{Mg}^{2+}$ is important. We thus propose $\mathbf{T 2 O H 1 C H}=\mathbf{N}-\mathbf{N H}-$ Pyri as a fluorescent chemosensor for this purpose.

\section{ACKNOWLEGEMENTS}

This work was supported by JSPS KAKENHI Grant Number 25410137 and 16K05805. The authors would like to thank Enago (www.enago.jp) for the English language review.

\section{REFERENCES}

[1] a) J. Kawakami, H. Kawaguchi, K. Kikuchi, A. Yamaya, S. Ito, and H. Kitahara, Trans. Mater. Res. Soc. Japan, 38, 123-125 (2013); b) J. Kawakami, Tryptanthrin Derivatives, Patent No. 5448046, Japan (Jan 10, 2014).

[2] a) J. Kawakami, A. Soma, K. Kikuchi, Y. Kikuchi, S. Ito, and H. Kitahara, Anal. Sci., 30, 949-954 (2014); b) J. Kawakami, K. Kikuchi, K. Chiba, N. Matsushima, A. Yamaya, S. Ito, M. Nagaki, and H. Kitahara, Anal. Sci., 25, 1385-1386 (2009).

[3] J. Kawakami, T. Kadowaki, M. Ikeda, Y. Habata, S. Ito, and H. Kitahara, Trans. Mater. Res. Soc. Japan, 41, 143146 (2016).
[4] J. Kawakami, A. Tsuiki, S. Ito, and H. Kitahara, Trans. Mater. Res Soc. Japan, 41, 131-133 (2016).

[5] J. Kawakami, M. Takahashi, S. Ito, and H. Kitahara, Anal Sci., 32, 251-253 (2016).

[6] K. König, J. Microscopy, 200, 83-104 (2000).

[7] J. Kawakami, Y. Kinami. M. Takahashi, and S. Ito, Trans. Mater. Res Soc. Japan, 43, 109-112 (2018).

[8] J. C. Duff and E. J. Bills, J. Chem. Soc., 1987-1988 (1932).

[9] a) F. GÖKtaŞ, N. Cesur, D. ŞAtana, M. Uzun Turk. $J$. Chem., 38, 581-591 (2014); b) P. Li and S. Xiao, J. Photochem. Photobiol. A: Chem., 330, 169-174 (2016).

[10] a) D. Parker and J. A. G. Williams, J. Chem. Soc., Perkin Trans. 2, 1305-1314 (1995); b) Y. Shiraishi, Y. Kohno, and T. Hirai, J. Phys. Chem. B, 109, 19139-19147 (2005).

[11] a) H. Benesi and J. Hildebrand, J. Am. Chem. Soc., 71, 2703-2707 (1949); b) S. Alves, F. Pina, M. T. Albelda, E. García-España, C. Soriano, and S. V. Luis, Eur. J. Inorg. Chem., 405-412 (2001).

[12] M. Kao, T. Chen, Y. Cai, C. Hu, Y. Liu, Y. Jhong, and A. Wu, J. Lumin., 169, 156-160 (2016).

(Received December 28, 2017; Accepted April 24, 2018; Published Online June 1, 2018) 